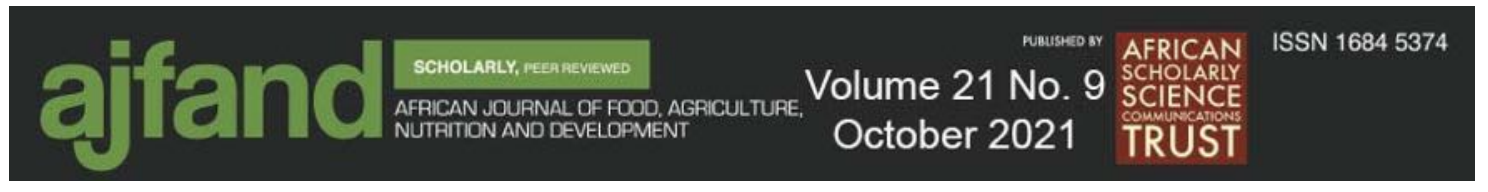

Afr. J. Food Agric. Nutr. Dev. 2021; 21(9): 18732-18747 $\quad$ https://doi.org/10.18697/ajfand.104.20460

\title{
COMPOSITIONAL, PHYSICO-MECHANICAL AND FUNCTIONAL PROPERTIES OF TWO GHANAIAN COWPEA (Vigna unguiculata) VARIETIES
}

Tawiah ER ${ }^{1,3}$, Akonor PT ${ }^{2,3 *}$, Oduro-Yeboah $C^{2,3}$, Idun-Acquah NN ${ }^{2}$, TK Tengey ${ }^{4}$, Mingle $\mathrm{CL}^{1}$ and P-N T Johnson ${ }^{3}$

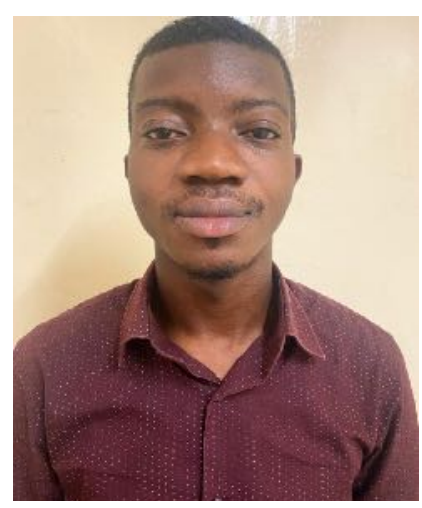

ER Tawiah

*Corresponding author email: papatoah@gmail.com

${ }^{1}$ Food and Drugs Authority, Box CT 2783, Accra, Ghana

${ }^{2}$ Council for Scientific and Industrial Research- Food Research Institute, Box M.20, Accra, Ghana

${ }^{3}$ Department of Agro-processing Technology and Food Biosciences, CSIR-College of Science and Technology, Box M.20, Accra, Ghana

${ }^{4}$ Council for Scientific and Industrial Research- Savanna Agricultural Research Institute, Box 52, Nyankpala, Ghana 


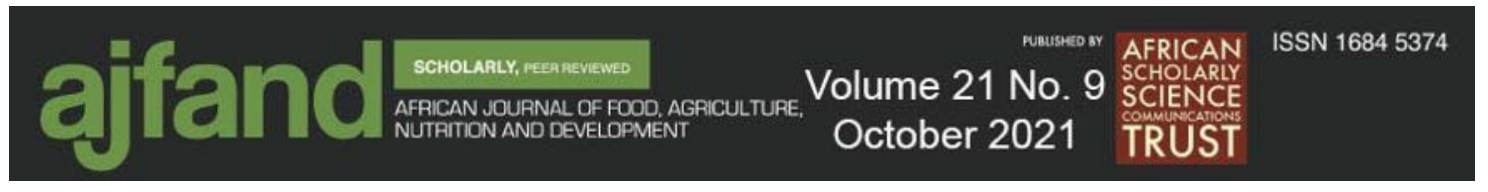

\begin{abstract}
Cowpea (Vigna unguiculata) is a legume that is cultivated throughout Africa and contributes a significant amount of plant-based protein to human diets. There are many varieties of cowpeas, and these have varying seed characteristics such as shape, size, colour and nutritional properties. The compositional, physico-mechanical, and functional properties of two new cowpea seed varieties were investigated in order to determine their full food-use potentials as well as key parameters for their postharvest machinery for processing, handling, and storage. The proximate composition of the two cowpea cultivars was determined using standard methods. Physico-mechanical analyses carried out were the hundred-seed weight and volume, bulk density, true density, size, aspect ratio, surface area, equivalent diameter, porosity and angle of repose. Functional properties determined were cooking time and water uptake of the grain as well as water and oil absorption, foam capacity and stability, and emulsion capacity and stability of the flour. The Padi-Tuya variety was longer, broader and thicker than Wang Kae. The results showed both varieties to be useful sources of macronutrients. The moisture, fat and fibre in Wang Kae were significantly higher $(\mathrm{p}<0.05)$ than Padi-Tuya. However, both cowpea varieties had comparable protein levels of $17.7 \mathrm{~g} / 100 \mathrm{~g}$. The cooking time, hydration capacities and indices of the two varieties were also significantly different $(\mathrm{p}<0.05)$, but their swelling capacities, swelling and water uptake indices were comparable. Cooking times were 40 and 62 min for Padi-Tuya and Wang Kae, respectively. The water and oil absorption capacities, as well as the swelling indices, were similar, but their emulsion capacities and stabilities were significantly different $(\mathrm{p}<0.05)$ for the flour. Padi-Tuya had a higher foam capacity, but was less stable, than Wang Kae. The physico-mechanical properties determined would aid in the design of cleaning, handling and other processing machinery as well as storage facilities for the new cowpeas. The functional and the compositional parameters would assist in the food formulations.
\end{abstract}

Key words: Cowpea (Vigna unguiculata) varieties; compositional; physico-mechanical and functional properties 


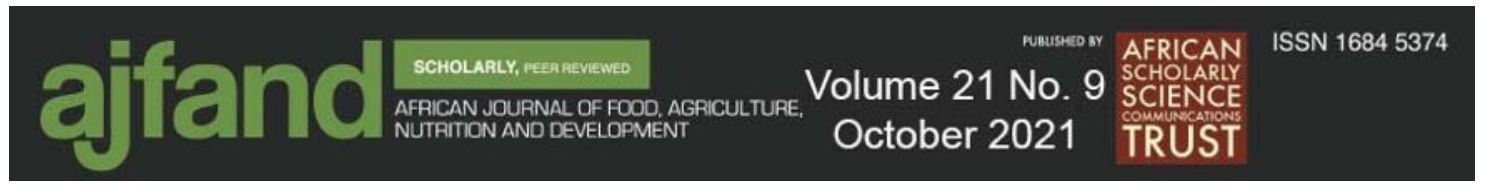

\section{INTRODUCTION}

Cowpea (Vigna unguiculata) is an important source of plant protein and therefore used in several tropical and subtropical countries all over the world. In Ghana, cowpea is primarily prepared and consumed wholly or as a component of a meal. It is used in a variety of dishes, including Koose (cowpea fritters), gari and beans (roasted grated fermented cassava and cooked beans), Tubani (steamed bean cake) stews and soups. These qualities make it an ideal crop for catering for the food security needs of several communities [1]. In Ghana, cowpea is primarily grown in the savannah, coastal, and transition zones [2]. The rainfall pattern in Ghana is such that the northern sector receives little rain, whereas the southern sector receives a lot. Due to disease and pest infestation, the wet conditions in the southern sector make it unsuitable for cowpea cultivation. The majority of cowpea is thus grown in northern Ghana as they are well suited to harsh farming conditions systems $[2,3]$.

Unfortunately, the current challenges with climate change in most farming systems in the tropics have brought on several biotic and abiotic factors that have affected the production, storage and even the processing of cowpea. In response to these effects, the Council for Scientific and Industrial Research (CSIR)-Savanna Agriculture Research Institute bred climate-resilient and high-yielding cowpea varieties like Padi-Tuya and Wang Kae. Padi-Tuya was bred in response to the low yields and long cooking times of some earlier varieties, whilst Wang Kae was developed to be early maturing, resistant to aphids and striga infestation, as well as address the problem of low yields and long cooking times.

Numerous researchers, including Adu-Dapaah and Addison [4], David and Acka [5], and Appiah et al. [1], have examined properties of previous cowpea varieties grown in Ghana, but none on these two. It is important that their full food-uses potential as well as key parameters needed for processing and handling machinery for these cowpeas are determined. The purpose of this study was, therefore, to assess the compositional, physico-mechanical and functional properties of these newly developed cowpea varieties.

\section{MATERIALS AND METHODS}

\section{Source of Cowpeas}

Padi-Tuya and Wang Kae, the two cowpea varieties used in this study, were obtained from experimental plots of the CSIR-Savanna Agricultural Research Institute's Cowpea Improvement Program. When the grains arrived, they were cleaned and sorted before being packaged into sacks and stored at the Food and Drugs Authority's Physicochemical Laboratory in Accra at temperatures of $28 \pm 2{ }^{\circ} \mathrm{C}$ and relative humidity of $75 \pm 5 \%$ until ready for use. 


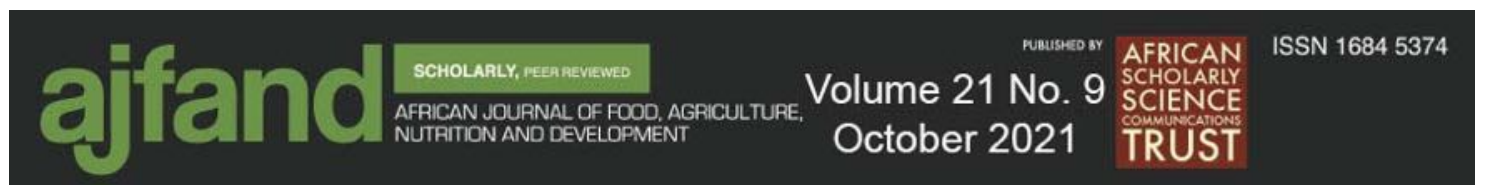

\section{Analyses of Physico-mechanical Properties}

\section{Weight and volume}

Both the hundred seed weight and volume were determined according to methods as explained by Wani et al. [6].

\section{Bulk and true density}

Bulk density $(D b)$ was determined by placing 100 randomly selected seeds into a measuring cylinder and recording the volume after gently tapping the cylinder on a table for a few minutes. The ratio of mass of seed to the volume recorded gave the bulk density [6]. True density $(D t)$, which is the ratio of mass of cowpea seed to the true volume of seeds, was determined by the toluene displacement method [6]. The volume of toluene displaced was determined by immersing a weighed quantity of cowpea seed in the toluene.

\section{Dimensions}

The length (L), breadth (B) and thickness (T), were determined using a digital vernier caliper with a least count of $0.01 \mathrm{~mm}$ (Mitutoyo, Japan). The length of the grains was determined by measuring the longest dimension (along the split of the cotyledon), while breadth and thickness were measured at the lateral and dorsal sides, respectively as described by Appiah et al. [1].

\section{Sphericity and surface area}

The sphericity of the cowpea seeds was calculated as a function of the three principal dimensions, as explained by Wani et al. [6], using the formula:

Sphericity $=\left[\frac{\sqrt[3]{L B T}}{L}\right] \times 100$

Where:

$\mathrm{L}=$ Length of cowpea grain;

$\mathrm{B}=$ Breadth of cowpea grain;

$\mathrm{T}=$ Thickness of cowpea grain

The surface area was calculated using the formula:

Surface area $=\frac{\pi B L^{2}}{2 L-B}$

Where:

$\mathrm{B}=$ Breadth of cowpea grain

$\mathrm{L}=$ Length of cowpea grain 


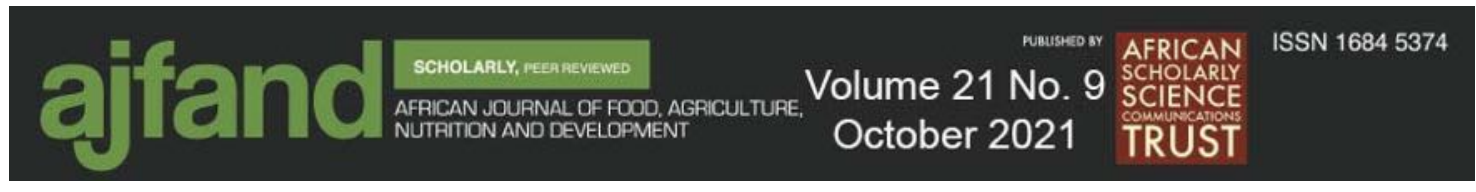

\section{Porosity}

The Porosity of the seeds was calculated using the formula:

Porosity $=\left[1-\left(\frac{D b}{D t}\right)\right] \times 100$

Where:

$D b=$ Bulk density

$D t=$ True Density

\section{Angle of repose}

Cowpea flour $(250 \mu \mathrm{m})$ was poured gradually into a funnel suspended $3 \mathrm{~cm}$ above a bench to form a heap on a paper at the base of the funnel. The diameter of a circle drawn around the heap was measured at four different points. Angle of repose was calculated using the formula below [7]:

Angle of Repose $=\tan ^{-1} \frac{h}{0.5 x d}$

Where:

$h=$ Height from the tip of the funnel to the bench

$d=$ Diameter of the circle drawn

\section{Proximate Composition}

Compositional analyses carried out on the cowpeas were moisture, ash, crude fat and crude fibre, protein and carbohydrates. Moisture was determined according to AOAC methods 934.01 [8], ash by AOAC method 942.05 [8] and crude fat and fibre by AOAC [8] methods, 920.39 and 978.10, respectively. Protein was determined by the Kjeldahl method (AOAC method 988.05) where the nitrogen content determined was multiplied by the factor 6.25 . Carbohydrate was estimated by difference.

\section{Analyses of Functional properties}

The functional properties determined were partly on the grains and partly on the flour. For the grains, the parameters determined were the hydration capacity and index, swelling capacity and index, water uptake ratio and cooking time. For flour, the parameters determined were water and oil absorption, foam capacity and stability, emulsion capacity and stability, swelling power and index.

\section{Hydration capacity and hydration index}

Five gram $(5 \mathrm{~g})$ of cowpea was soaked in $50 \mathrm{~mL}$ distilled water in a measuring cylinder [9]. The seeds were left to soak for $24 \mathrm{~h}$ at room temperature, drained and the excess water blotted with tissue paper. Thereafter, the weight of swollen seeds was measured and the hydration capacity and index were, respectively calculated using the formulae:

Hydration Capacity $=\frac{\text { Weight after soaking-Weight before soaking }}{\text { Number of grains }}$ 


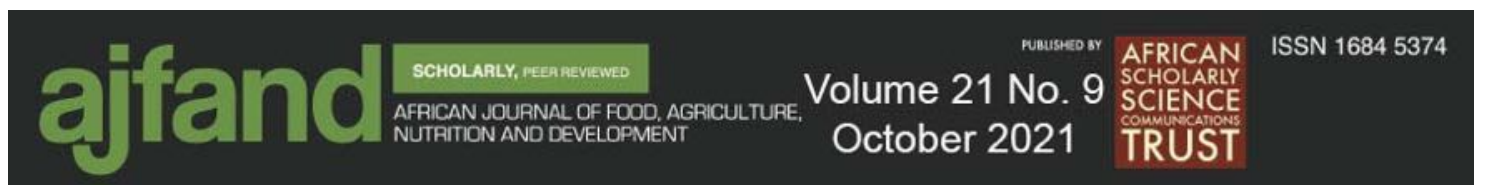

Hydration Index $=\frac{\text { Hydration Capacity }}{\text { Weight of one seed }}$

\section{Water uptake ratio}

About $20 \mathrm{~g}$ of cowpea seeds were cooked in $200 \mathrm{ml}$ of distilled water for minimum cooking time [10]. Cooked seeds were removed, drained and excess water blotted with tissue paper. The seeds were weighed and the water uptake ratio determined as a ratio of weight gained after cooking to weight before cooking.

\section{Cooking time}

Cooking time was determined according to Wani et al. [10] with slight modifications. In brief, $200 \mathrm{~mL}$ distilled water was boiled in a flask fitted with reflux condenser to prevent water loss during cooking. Thirty gram $(30 \mathrm{~g})$ of cowpea seeds were added to the flask and boiled for $30 \mathrm{~min}$. After this period three to five seeds were withdrawn using tweezers at 2 min intervals and tested for softness by pressing between fingers and the thumb. The time from addition of seeds till attainment of a desired softness was recorded as the cooking time.

\section{Water and oil absorption properties}

Water and oil absorption capacities, foam capacity and stability were determined according to methods described by Appiah et al. [1], emulsion capacity and stability by Sridaran et al. [11], and then finally swelling power and index of the cowpea flour by methods of Appiah et al. [1] and Adebowale et al. [9], respectively.

\section{Statistical Analysis}

Quantitative variables were summarized using means and standard deviations. Student's $t$-test was carried out using Minitab Release 17 statistical software (Minitab Inc., USA) to determine differences in means at 95\% confidence level.

\section{RESULTS AND DISCUSSION}

\section{Physico-mechanical Properties}

The dimensional analysis of Padi-Tuya and Wang Kae showed that Padi-Tuya is significantly $(\mathrm{p}<0.05)$ longer, broader and thicker than Wang Kae, as indicated by the breadth and thickness (Figure 1). 

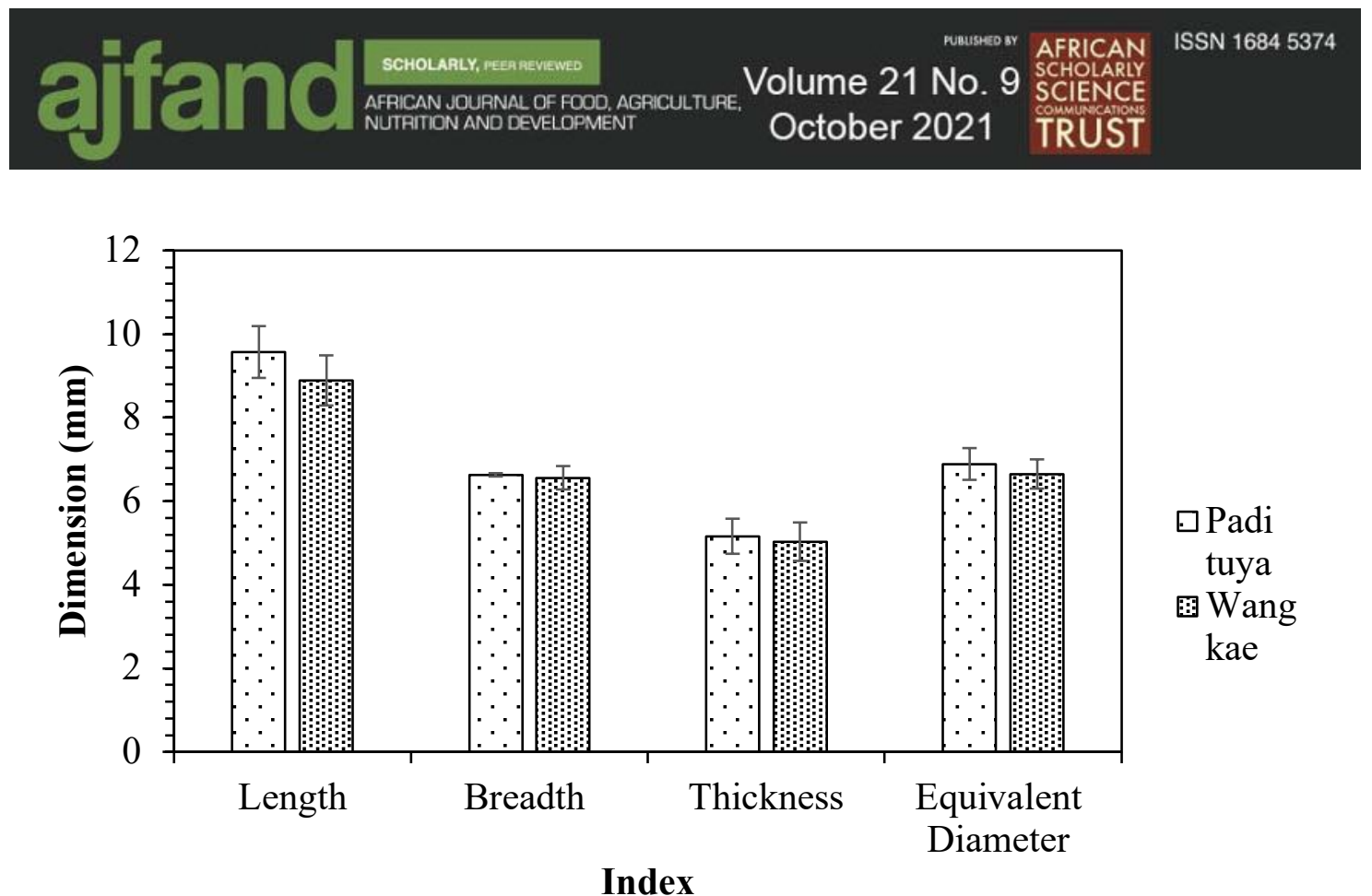

Figure 1: Spatial dimensions of Padi-Tuya and Wang Kae cowpea varieties (means with standard deviation (SD) error bars)

The dimensional sizes of all these new varieties were also significantly higher than those of previous Ghanaian cowpea varieties, Nhyria, Tona and Adom, as reported by Appiah et al. [1]. The lengths, breadths and thicknesses of these previous varieties were 7.6, 5.9 and $4.5 \mathrm{~mm}$, respectively, for Nhyira variety; $7.7 \mathrm{~mm}, 5.8 \mathrm{~mm}$ and $4.6 \mathrm{~mm}$, respectively, for Tona variety; and $7.7 \mathrm{~mm}, 6.3 \mathrm{~mm}$ and $4.9 \mathrm{~mm}$, respectively, for Adom variety. These differences might influence the size of the screens used in rotary vibratory screens typically used for cleaning cowpeas during industrial processing [12]. Cleaning of cowpea is one of the critical unit operations during the processing of end products from cowpea. This is because cowpeas have high tendency to be contaminated with other materials such as earth, small pebbles, plant and insect waste as well as immature seeds.

An additional implication of the relatively bigger size of Padi-Tuya could be due to the use of hermetic systems to store these cowpeas. Cowpea is usually heavily attacked by storage pests and one method of eradicating such pests is through the use of hermetic storage, which creates an oxygen-depleted, carbon dioxide-rich atmosphere that is lethal to storage insects [13]. In hermetic storage systems, a modified atmosphere condition is created, in which the oxygen concentration is gradually reduced whilst the carbon dioxide concentration increases with time, through respiration of both the commodity and insects [14]. Cowpea grain size influences the movement of oxygen in hermetic containers used for cowpea grain storage. When grains are bulkier and bigger, they do not pack well in silos and therefore will create big spaces between grains facilitating easier movement of oxygen between the bigger grains than between the smaller grains. This means the time required to reach low oxygen levels in hermetic storage systems for Padi-Tuya, through respiration effects, may be longer than in those of Wang Kae and earlier cowpea varieties, with relatively smaller sizes. 


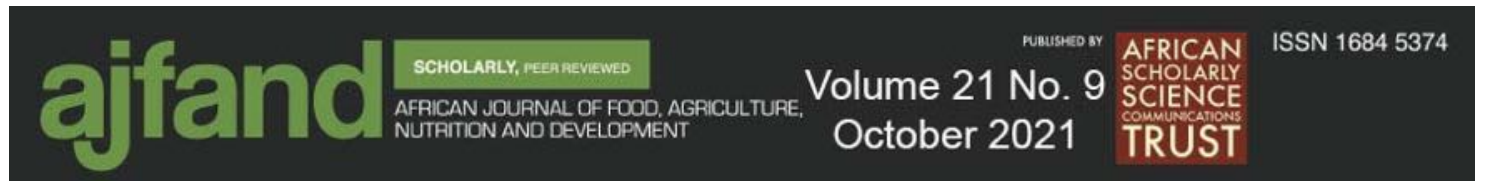

The 100 grain seed weights of Padi-Tuya and Wang Kae were 20.5 and 18.7 g, respectively (Table 1). These were heavier compared to those of Nhyira, Tona and Adom varieties that were $13.2 \mathrm{~g}, 14.2 \mathrm{~g}$ and $15.2 \mathrm{~g}$, respectively [1], and $13.1 \mathrm{~g}$ and $9.9 \mathrm{~g}$, respectively for red and black cowpea [15]. The grain bulk and true densities, grain weight and volume are important factors to consider when designing and using industrial rotary cleaning machines for these cowpea grains. The 100 grain seed weight and volume were significantly different $(\mathrm{p}<0.05)$ between Padi-Tuya and Wang Kae. Angle of repose was higher $(\mathrm{p}<0.05)$ in Wang Kae than Padi-Tuya. Previous values reported for other legumes were lower, and ranged between $17.7-19.0^{\circ}$ for black gram [10], 26.6 - 31.1 for green gram [16] and $18-31$ for pigeon pea [17]. A significantly higher porosity was observed for Padi-Tuya, implying that this variety would hydrate easier compared to Wang Kae [18].

\section{Compositional Properties}

Compositional properties of the two cowpea varieties are summarized in Table 2 . There was no significant difference $(\mathrm{p}>0.05)$ between the ash, protein and carbohydrate content of the two varieties. However, the fat, fibre and moisture levels of the two varieties were markedly different. The moisture content of Padi-Tuya and Wang Kae in this study were comparable those of Nhyira, Tona and Adom, which had 9.79, 9.15 and $9.83 \%$, respectively [1]. Otitoju et al. [19] reported the moisture content of Potiskum, Ife-brown, Orarudi and Aloka varieties to be 13.48, 14.5, 11.5 and $12.91 \%$, respectively. Affrifah [20] has observed that high moisture content ( $>13 \%)$ before storage could lead to the development of hard-to-cook defect in cowpea. Since their moisture contents were lower than $13 \%$, the probability of these varieties developing the hard-to-cook defect is low, with Padi-Tuya being lower than Wang Kae in moisture content.

The protein content of Padi-Tuya and Wang Kae was comparable. These had lower protein contents compared to some varieties previously reported by Kaptso et al. [21], Appiah et al. [1], Tresina and Mohan [22] and Kaptso et al. [23]. The amount of protein in cowpea is important because proteins are the main molecules that imbibe water in seeds [4]. The high protein content of cowpea, has been known to reduce protein energy disorders such as Kwashiorkor [1]. The quality and quantity of protein in cowpea makes it a good complementary food with cereals.

Total ash for the two varieties was 3.7\% and this was higher than the ash content reported for some other varieties. For instance, Appiah et al. [1] recorded 2.9, 3.0 and $3.2 \%$, respectively, for Nyhira, Tona and Adom. The amounts of fat in Padi-Tuya and Wang Kae were lower than the values reported by Appiah et al. [1] for Nhyira (2.5\%), Tona (2.5\%) and Adom (4.0\%) varieties of cowpea The fat content of cowpea pastebased foods like Koose or Akara improves their palatability [1,21]. The 4.6 percent mean fibre content in this study was comparable to values reported for the Nhyira, Tona, and Adom cowpea varieties [1]. The dietary fibre has been shown to help with digestion, blood sugar regulation, and diabetic patients [24]. 


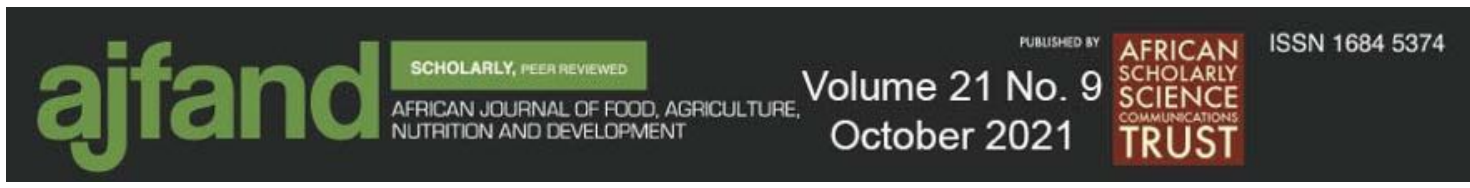

\section{Cooking Characteristics}

Table 3 shows that Padi-Tuya had a significantly $(\mathrm{p}<0.05)$ shorter cooking time of 42 minutes compared to Wang Kae which required 62 minutes to cook to desirable texture. This indicates that Padi-Tuya would require less energy for processing. The difference in cooking time may be attributed to differences in their hydration properties, and this may be linked to differences in their protein content [25], even though this was marginal. Additionally, the higher porosity of Padi-Tuya seeds may have played an influential role. High hydration and swelling capacities are desirable in cowpea processing as they reduce cooking time by increasing energy transfer to the grain [24]. Cooking time of the cowpea in this study was longer than the range ( $24-42.5$ minutes) reported by Addo et al. [26], but comparable to some varieties ( $35-57$ minutes) studied by Olapade et al. [27] and Nhyira (57 minutes) and Tona (65 minutes) as reported by Appiah et al. [1]. Other varieties reported by Olapade et al. [27] and Appiah et al. [1] had longer cooking times of 80 and 84 minutes, respectively, compared to Padi-Tuya and Wang Kae. Compositional, structural and genetic variations may be responsible for these reported differences. Even though cooking improves the digestibility of proteins and carbohydrates, prolonged cooking is undesirable and may affect protein quality. Long cooking time may also lead to loss of nutrient and undesirable quality [20]. The seed swelling capacity, swelling index and water uptake ratio did not necessarily affect their cooking time. Swelling capacity and index for these two varieties were higher than $0.05 \mathrm{~mL} / \mathrm{seed}$ and 0.001 reported correspondingly for these indices by Tresina and Mohan [22]. The swelling capacity was, however, lower than $2.3-3.2 \mathrm{~mL} /$ seed reported by Olapade et al. [27].

\section{Functional Properties of cowpea flour}

Cowpea flour is a versatile food ingredient with wide application in the production of Akara, Moinmoin and bakery products [28]. Its performance in these products depends on the flour functionality, and this is largely dictated by protein and carbohydrate composition. In this study, results of some key functional properties evaluated are summarized in Table 4.

A mean of 1.4 and $1.1 \mathrm{~g} / \mathrm{g}$ flour was, respectively, recorded for water absorption capacity and oil absorption capacity in the two cowpea varieties. For these parameters, there were no significant differences $(\mathrm{p}>0.05)$ between the two cowpea varieties. Higher water absorption capacities of $1.6-1.9 \mathrm{~g} / \mathrm{g}$ flour and $2.1-2.8 \mathrm{~g} / \mathrm{g}$ flour have been respectively reported by Chinma et al. [29] and Olaofe et al. [30] for some Nigerian varieties. Ghanaian varieties studied by Appiah et al. [1] also had higher water absorption capacity $(1.9-2.2 \mathrm{~g} / \mathrm{g}$ flour $)$ and oil absorption capacity $(2.0-2.3 \mathrm{~g} / \mathrm{g}$ flour $)$ than the varieties used in the present study. While swelling power and true density differed significantly, the bulk densities of the cowpea were quite similar. The swelling power was higher than the 2.7 reported in a similar study [1]. The emulsion capacity of Padi-Tuya and Wang Kae was approximately the same, but the latter formed a more stable emulsion. Proteins in flour aid in the formation of emulsions and, therefore, the low emulsion stability of Padi-Tuya, could be due to the slow diffusion of the proteins to the interfacial area to stabilize the emulsion [31]. The emulsion capacity observed in this study was much lower than that observed by Hamid et al. [32] for red and black 


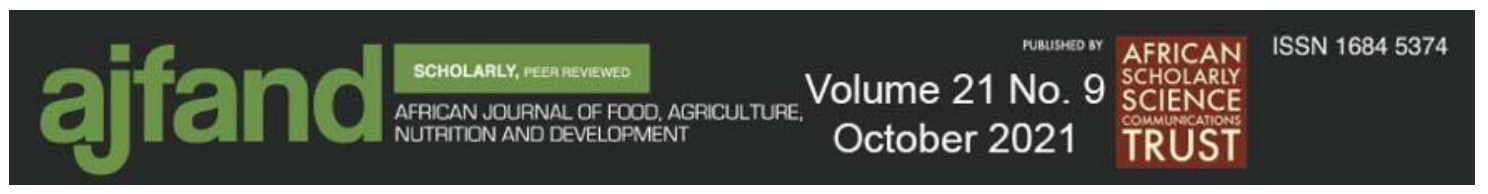

cowpea varieties, which were 35 and $34 \%$, respectively. The emulsion stability of the cowpea varieties by Hamid et al. [32] was also higher ( $96 \%$ and $74 \%)$ than what was observed in this study, which could be due to differences in protein structure and functionality.

Foaming properties were significantly different $(\mathrm{p}<0.05)$ for the two varieties, with Padi-Tuya having higher foam capacity with less stability compared to Wang Kae (Figure 2).

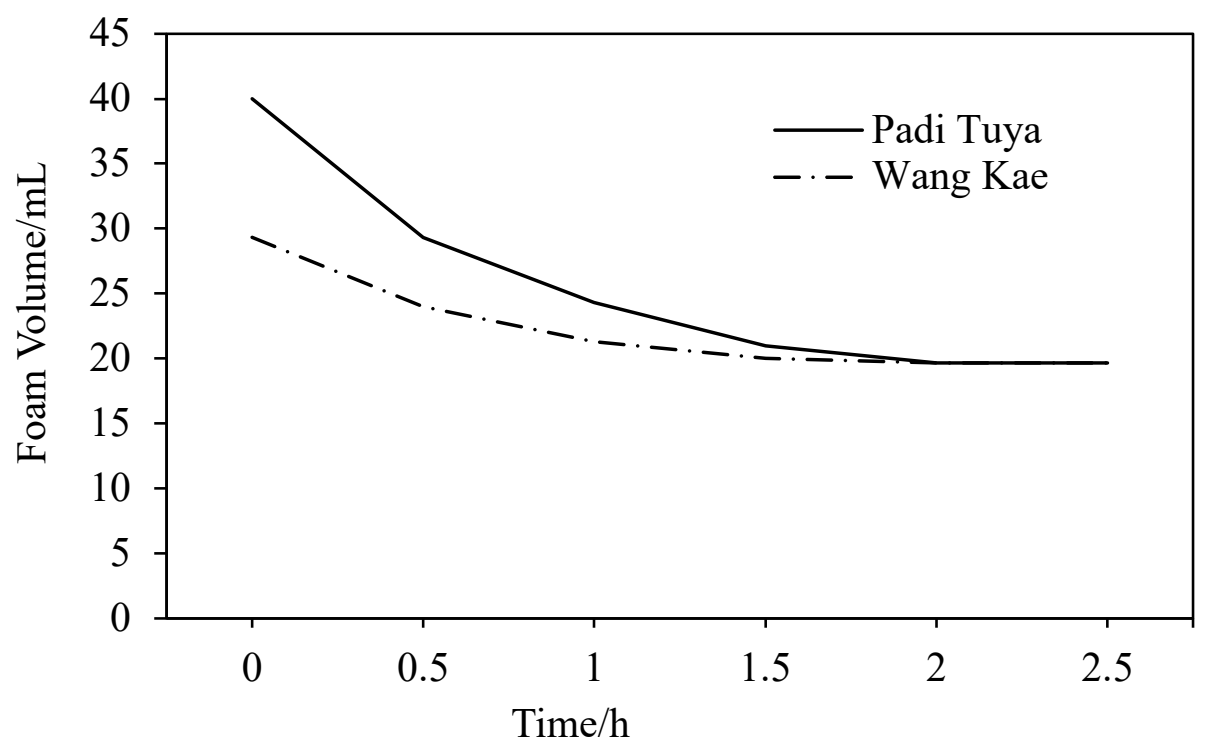

Figure 2: Foam stability of flour of Padi-Tuya and Wang Kae cowpea varieties

Foaming in cowpea is associated with the high- water solubility of cowpea protein and its ability to form stable layers around gas bubbles in a liquid phase [33]. As indicated by Kethireddipalli et al. [34], foaming is important for the development of desirable texture in Akara, a product made from cowpea flour. Foaming capacity of the varieties used in this study was higher than the reported range of 10-21\% [1] but within $40-$ $80 \%$ for cowpea flour [30]. Variations in the functional properties of two varieties and others reported in related literature may be ascribed to compositional differences, physical properties, genetic variations and growing conditions.

\section{CONCLUSION}

The two cowpea varieties had differences in their physico-mechanical, compositional and cooking properties as well as marked differences in the functional properties of their flours. Their compositional properties indicate that they are valuable sources of macronutrients, making them potentially useful in diets. While their functional properties exhibit the suitability of the two cowpea varieties in processing, the physicomechanical properties of Padi-Tuya and Wang Kae provide data that would influence the design and operations industrial cleaning machinery for the cowpea grains. 


\section{ACKNOWLEDGEMENTS}

We wish to acknowledge the assistance of technical staff at the Food Physicochemical Unit of Food and Drugs Authority of Ghana.

\section{DECLARATION OF COMPETING INTEREST}

The authors declare that they have no interest to declare for this publication. 


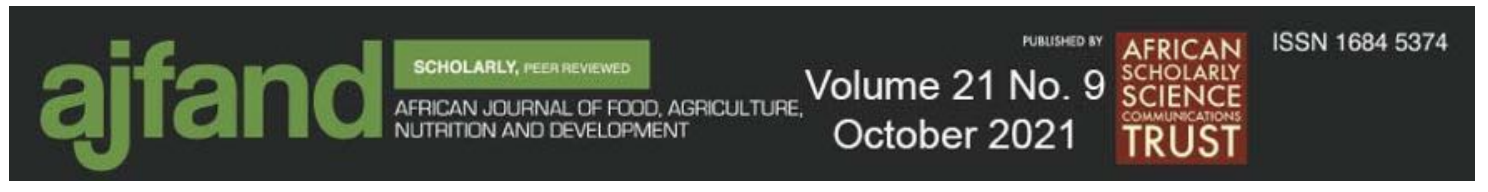

Table 1: Physico-mechanical properties of Padi-Tuya and Wang Kae cowpea varieties

\begin{tabular}{lll}
\hline \multicolumn{1}{c}{$\begin{array}{c}\text { Physico-mechanical } \\
\text { property }\end{array}$} & \multicolumn{2}{c}{ Cowpea varieties } \\
\cline { 2 - 3 } & Padi-Tuya & Wang Kae \\
\hline Grain Bulk density $\left(\mathrm{g} / \mathrm{cm}^{3}\right)$ & $0.72 \pm 0.01^{\mathrm{a}}$ & $0.75 \pm 0.01^{\mathrm{a}}$ \\
Grain True density $\left(\mathrm{g} / \mathrm{cm}^{3}\right)$ & $1.13 \pm 0.05^{\mathrm{a}}$ & $1.15 \pm 0.05^{\mathrm{a}}$ \\
Porosity (\%) & $35.59 \pm 2.83^{\mathrm{a}}$ & $33.72 \pm 4.26^{\mathrm{a}}$ \\
100 Grain seed volume & $16.67 \pm 0.58^{\mathrm{a}}$ & $14.67 \pm 0.58^{\mathrm{b}}$ \\
$\left(\mathrm{cm}^{3}\right)$ & & \\
100 Grain seed weight $(\mathrm{g})$ & $20.54 \pm 0.18^{\mathrm{a}}$ & $18.69 \pm 0.14^{\mathrm{b}}$ \\
Sphericity (\%) & $72.09 \pm 2.91^{\mathrm{a}}$ & $74.71 \pm 3.43^{\mathrm{b}}$ \\
Surface area $\left(\mathrm{mm}^{2}\right)$ & $152.95 \pm 15.78^{\mathrm{a}}$ & $145.29 \pm 12.24^{\mathrm{b}}$ \\
Angle of Repose $\left(^{\circ}\right)$ & $40.24 \pm 1.67^{\mathrm{a}}$ & $45.30 \pm 1.22^{\mathrm{b}}$ \\
\hline
\end{tabular}

*Within a row, means bearing different superscripts are significantly different $(\mathrm{p}<0.05)$

Table 2: Proximate composition of Padi-Tuya and Wang Kae cowpea varieties

\begin{tabular}{lll}
\hline \multicolumn{1}{c}{ Proximate } & \multicolumn{2}{c}{ Cowpea varieties } \\
\cline { 2 - 3 } & Padi-Tuya & Wang Kae \\
\hline Moisture $(\mathrm{g} / 100 \mathrm{~g})$ & $10.11 \pm 0.06^{\mathrm{a}}$ & $10.79 \pm 0.14^{\mathrm{b}}$ \\
Ash $(\mathrm{g} / 100 \mathrm{~g})$ & $3.66 \pm 0.04^{\mathrm{a}}$ & $3.68 \pm 0.08^{\mathrm{a}}$ \\
Fat $(\mathrm{g} / 100)$ & $0.89 \pm 0.03^{\mathrm{a}}$ & $1.51 \pm 0.14^{\mathrm{b}}$ \\
Protein $(\mathrm{g} / 100 \mathrm{~g})$ & $18.31 \pm 0.77^{\mathrm{a}}$ & $17.16 \pm 0.93^{\mathrm{a}}$ \\
Carbohydrate $(\mathrm{g} / 100 \mathrm{~g})$ & $62.01 \pm 0.08^{\mathrm{a}}$ & $63.17 \pm 0.73^{\mathrm{a}}$ \\
Fibre $(\mathrm{g} / 100 \mathrm{~g})$ & $5.03 \pm 0.05^{\mathrm{a}}$ & $4.12 \pm 0.23^{\mathrm{b}}$
\end{tabular}

*Within a row, means bearing different superscripts are significantly different $(\mathrm{p}<0.05)$ 


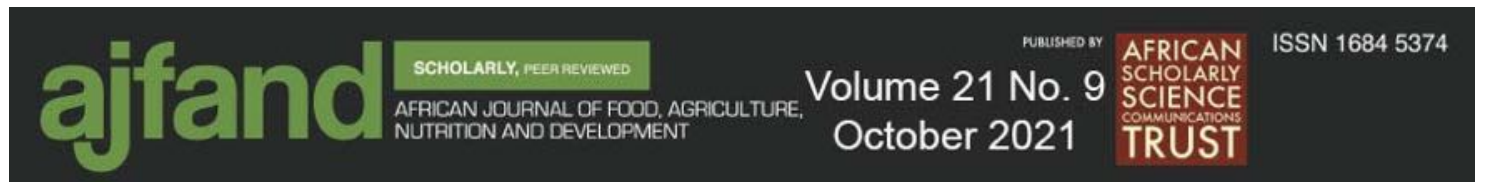

Table 3: Cooking characteristics of Padi-Tuya and Wang Kae cowpea varieties

\begin{tabular}{lcc}
\hline \multirow{2}{*}{ Cooking characteristics } & \multicolumn{2}{c}{ Cowpea varieties } \\
\cline { 2 - 3 } & $0.24 \pm 0.01^{\mathrm{a}}$ & $0.19 \pm 0.01^{\mathrm{b}}$ \\
\hline Hydration capacity (mL/seed) & $0.53 \pm 0.01^{\mathrm{a}}$ & $0.52 \pm 0.01^{\mathrm{b}}$ \\
Hydration index & $0.24 \pm 0.01^{\mathrm{a}}$ & $0.29 \pm 0.01^{\mathrm{a}}$ \\
Swelling capacity (mL/seed) & $0.56 \pm 0.01^{\mathrm{a}}$ & $0.62 \pm 0.01^{\mathrm{a}}$ \\
Swelling index & $2.21 \pm 0.02^{\mathrm{a}}$ & $2.26 \pm 0.03^{\mathrm{a}}$ \\
Water Uptake ratio & $42.33 \pm 2.52^{\mathrm{a}}$ & $62.33 \pm 2.52^{\mathrm{b}}$ \\
Cooking time (min) &
\end{tabular}

*Within a row, means bearing different superscripts are significantly different $(\mathrm{p}<0.05)$

Table 4: Functional properties of flour from Padi-Tuya and Wang Kae cowpea varieties

\begin{tabular}{lcc}
\hline \multicolumn{1}{c}{$\begin{array}{c}\text { Functional } \\
\text { Property }\end{array}$} & \multicolumn{2}{c}{ Cowpea varieties } \\
\cline { 2 - 3 } & Padi-Tuya & Wang Kae \\
\hline Water absorption capacity $(\mathrm{g} / \mathrm{g}$ & $1.42 \pm 0.11^{\mathrm{a}}$ & $1.31 \pm 0.04^{\mathrm{a}}$ \\
flour) & & \\
Oil absorption capacity (g/g flour) & $1.14 \pm 0.05^{\mathrm{a}}$ & $1.15 \pm 0.03^{\mathrm{a}}$ \\
Swelling power & $8.35 \pm 0.10^{\mathrm{a}}$ & $7.90 \pm 0.03^{\mathrm{b}}$ \\
True density $\left(\mathrm{g} / \mathrm{cm}^{3}\right)$ & $1.39 \pm 0.01^{\mathrm{a}}$ & $1.43 \pm 0.02^{\mathrm{b}}$ \\
Bulk density $\left(\mathrm{g} / \mathrm{cm}^{3}\right)$ & $0.87 \pm 0.01^{\mathrm{a}}$ & $0.89 \pm 0.01^{\mathrm{a}}$ \\
Emulsion capacity $(\%)$ & $6.11 \pm 0.10^{\mathrm{a}}$ & $6.11 \pm 0.96^{\mathrm{a}}$ \\
Emulsion stability $(\%)$ & $34.03 \pm 3.18^{\mathrm{a}}$ & $47.92 \pm 3.61^{\mathrm{b}}$ \\
Foam capacity $(\mathrm{mL})$ & $40.00 \pm 2.00^{\mathrm{a}}$ & $29.33 \pm 1.15^{\mathrm{b}}$ \\
\hline
\end{tabular}

*Within a row, means bearing different superscripts are significantly different $(\mathrm{p}<0.05)$ 


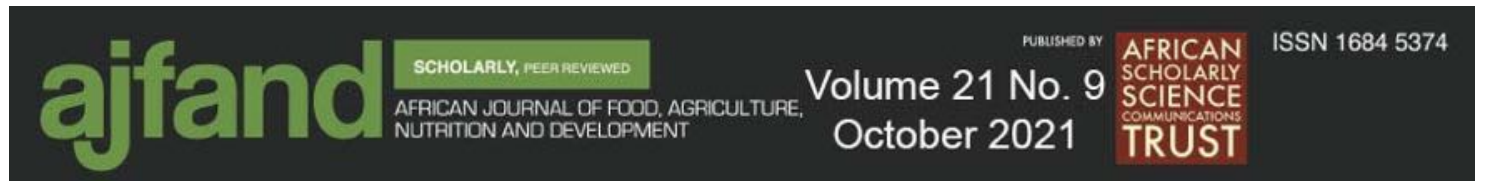

\section{REFERENCES}

1. Appiah F, Asibuo JY and P Kumah Physicochemical and functional properties of bean flours of three cowpea (Vigna unguiculata L. Walp) varieties in Ghana. Afric. J. Food Sci. 2011; 5(2): 100 - 104.

2. Akpalu MM, Salaam M, Oppong-Sekyere D and SE Akpalu Farmers' Knowledge and cultivation of cowpea (Vigna unguiculata (L.) Verdc.) in three communities of Bolgatanga municipality, Upper East Region, Ghana. Br. J. Appl. Sci. Technol., 2014; 4(5): 775 - 792.

3. Singh BB, Asante SK, Ajeigbe $\mathbf{H}$ and SG Mohammed General guide for cowpea cultivation and seed production. Bri. J. Appl. Sci. Technol.2014; 4(5): $775-792$.

4. Adu-Dapaah KAH and $\mathbf{P}$ Addison Variation in contents of crude protein and mineral elements in 32 cowpea (Vigna unguiculata (L.) Walp) accessions in Ghana. Ghana. J. of Agric. Sci. 2006; 39: 83 - 86.

5. David O and GK Acka Comparative studies on proximate composition of cowpea, maize and soft wheat flours in Ghana. Nutr Food Toxicol. 2018; 3(3): $680-685$.

6. Wani IA, Sogi DS, Wani AA and BS Gill Physical and cooking characteristics of some Indian kidney bean (Phaseolus vulgaris L.) cultivars. J. Saudi Soc. of Agric. Sci., 2015; 1 - 9.

7. Tadesse FT Handbook of farm, dairy and food machinery engineering. $3^{\text {rd }}$ edition, Amsterdam, Netherlands: Elsevier Inc, 2019.

8. Association of Official Analytical Chemists. Official methods of analysis of AOAC International. 18 ${ }^{\text {th }}$ edition. Maryland, USA: AOAC International, 2006.

9. Adebowale YA, Adeyemi IA and AA Oshodi Functional and Physicochemical properties of flours of six mucuna species. Afric J. Biotechnol, 2005; 4 (12): 1461 $-1468$.

10. Wani IA, Sogi DS and BS Gill Physical and cooking characteristics of black gram (Phaseolus mungoo L.) cultivars grown in India. Int. J. Food Sci. Technol., 2013; 48: 255 - 2563.

11. Sridaran A, Karim AA and R Bhat Pithecellobium jiringa legume flour for potential food applications: Studies on their physico-chemical and functional properties. Food Chem. 2012; 130: 528 - 535.

12. Irtwange SK Design, fabrication and performance of motorized cowpea thresher for Nigerian Small-scale farmers. African. J. of Agric. Res., 2009; 4 (12): 13831391. 


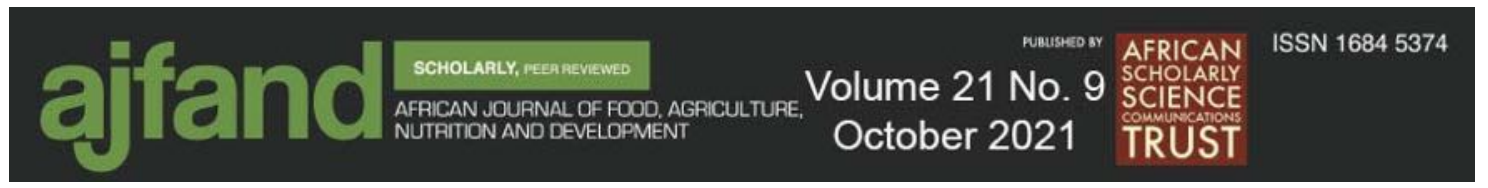

13. Yeole NR and KC Swain Hermetic storage technology for smallholder farmers in India. Aayushi Int. Interdis. Res. J., 2018; 4 (25): 91 - 95.

14. De Carli, M, Bresolin, B, Norena, CPZ and A Brandelli Efficacy of modified atmosphere packaging to control Sitophilus spp. In organic maize grain. Braz. Arch. Biol. Technol. 2010; 53:1469 - 1476.

15. Hamid S, Muzzafar S, Wani AI, Masoodi FA and MM Bhat Physical and cooking characteristics of two cowpea cultivars grown in temperate Indian climate. J Saudi Soc. Agric. 2016; 15: 127 - 134.

16. Nimkar MP and KP Chattopadhyay Some physical properties of green gram. $J$. Agric. Eng. Res. 2001; 80: 183-189.

17. Baryeh EA and BK Mangope Some physical properties of QP-38 variety pigeon pea. J. Food Eng. 2002; 56: 59-65.

18. Marabi A and IS Saguy Effect of porosity on rehydration of dry food particulates. J. Sci. Food Agric. 2004; 84: 1105-1110.

19. Otitoju GTO, Otitiju O, Nwamarah JU and SO Baiyeri Comparative study of the nutrient composition of four varieties of cowpea (Vigna unguiculata) and their products (Beans-based products). Pak. J. Nutr. 2015; 14 (9): 540 - 546.

20. Affrifah NS Improving the textural properties and storage stability of cowpeas: process development and evaluation. $\mathrm{PhD}$ Thesis submitted to the University of Georgia, Athens, Georgia. 2004.

21. Kaptso GK, Njintang NY, Nguemtchouin MGM, Amungwa AF, Scher J, Hounhouigan $\mathbf{J}$ and $\mathbf{C M F}$ Mbofung Characterization of morphology and structural and thermal properties of legume flours: cowpea (Vigna unguiculata L. Walp) and Bambara Groundnut (Vigna subterranean L. Verdc.) varieties. Int. J. Food Eng. 2015; 12:2. https://doi.org/10.1515/ijfe-2014-0146

22. Tresina PS and VR Mohan Physicochemical and antinutritional attributes of gamma irradiated Vigna unguiculata (L) Walp. Subsp. Unguiculata seeds. Int. Food Res. J., 2012; 19:639-646.

23. Kaptso KG, Njintang YN, Komnek AE, Hounhouigan J, Scher J and CMF Mbofung Physical properties and rehydration kinetics of two varieties of cowpea (Vigna unguiculata) and Bambara groundnuts (Voandzeia subterranean) seeds. J. Food Eng., 2008; 86:91-99.

24. Mogos T, Dondoi C and AEA Iacobini Review of dietary fibre in the diabetic diet. Rom. J. Diabetes Nutr. Metabol. Dis. 2017; 24 (2): 161 - 164. 


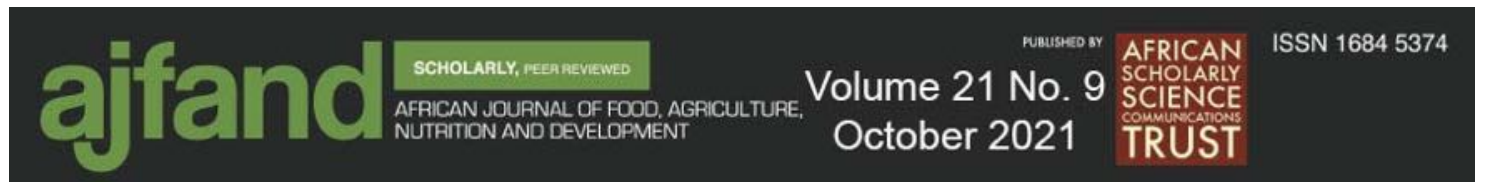

25. Mwangwela AM Physicochemical characteristics of conditioned and micronized cowpeas and functional properties of resultant flours. $\mathrm{PhD}$ Thesis submitted to University of Pretoria, South Africa 2006.

26. Addo JK, Amoah S, Boateng AM, Okyere H, Adu-Dapaah H and A AmoaOwusu Physical, functional and cooking characteristics of six newly released cowpea (Vigna unguiculate (L) Walp) varieties in Ghana. Agric. Food Sci. J. Ghana 2016; 9:742-753.

27. Olapade AA, Okafor GI, Ozumba AU and O Olatunji Characterization of common Nigerian cowpea (Vigna unguiculata L. Walp) varieties. J. Food Eng. 2002; 55:101-105.

28. McWatters KH, Ouedraogi JB, Resurreccion AVA, Hung Y-C and RD Phillips Physical and sensory characteristics of sugar cookies containing mixtures of wheat, fonio (Digitaria exilis) and cowpea (Vigna unguiculata) flours. Int. J. Food Sci. Technol. 2003; 38: 403 -410.

29. Chinma CE, Alemede IC and IG Emelife Physicochemical and Functional Properties of Some Nigerian Cowpea Varieties. Pak. J. Nutr. 2008; 7(1): 186 190.

30. Olaofe O, Umar YO and GO Adediran The effect of nematicides on the nutritive value and functional properties of cowpea seeds (Vigna unguiculata L. Walp.). Food Chem. 1993; 46: 337-341.

31. Cabra V, Arreguin R, and A Farres (2008). Emulsifying properties of proteins. Boletin de la Sociedad Quimica de Mexico, 2 (2): 80-89.

32. Hamid S, Muzzafar S, Wani AI and FA Masoodi Physicochemical and functional properties of two cowpea cultivars grown in temperate Indian climate. Cogent Food Agric. 2015; 1: 1 - 11.

33. Rangel A, Domont GB, Pedrosa $\mathbf{C}$ and $\mathbf{S}$ Ferreira Functional properties of purified vicilins from cowpea (Vigna unguilata) and pea (Pisum sativum) and cowpea protein isolate. J. Agric. Food Chem. 2003; 51: 5792-5797.

34. Kethireddipalli P, Hung Y-C, McWatters KH and RD Phillips Effect of milling method (wet and dry) on the functional properties of cowpea (Vigna unguiculata) pastes and end product (akara) quality. J. Food Sci. 2002; 67: 4852. 